\author{
E.T. Adilova1 ${ }^{1}$, O.Kh. Aimaganbetova ${ }^{1}$ iD, \\ A. Serikkhan ${ }^{1}$, S.K. Zhantikeyev ${ }^{2}$, L.Kasym ${ }^{3}$ \\ 1Al-Farabi Kazakh National University, Kazakhstan, Almaty, e-mail: elnura.adilova@mail.ru, \\ e-mail: alnara25@mail.ru, e-mail: ajoxot@gmail.com \\ ${ }^{2}$ Astana-Turan University, Kazakhstan, Nur-Sultan, e-mail: zhantikeyev_serik@mail.ru \\ ${ }^{3}$ University of Guelf, Canada, e-mail: 1.kassym@gmail.com
}

\title{
THE POSITION AND ROLE OF THE VALUE ORIENTATIONS SYSTEM IN THE STRUCTURE OF PERSONALITY
}

This article is devoted to the study of the place and role of the system of value orientations in the structure of personality. The relevance of this problem is due to the fact that in modern conditions of political, economic and social transformations, value orientations acquire special significance, since they determine the functioning and development of the personality as a whole.

The article presents various concepts and points of view, the focus of which is the problem of determining the main determinants of value orientations, as well as their place and role in the structure of personality. This is, first of all, the concepts of Russian psychologists - A.N. Leontiev, B.G. Ananyeva, A.V. Petrovsky, N.R.Salikhova, foreign - J. Piaget, L. Langle, N. Howe and W. Strauss and others. Of great interest is the competency development model considered here, formulated by Kazakhstan researcher D.T. Ikhsanova in the framework of the integrative approach of V.V. Kozlova. The article considers in detail the three levels of development of value orientations proposed by the author, which gave us the opportunity to determine their place and role in the structure of personality.

The review made it possible to formulate the following conclusions that value orientations are an important component of the personality structure, which manifests itself in all spheres of a person's life and regulates his behavior.

Key words: value orientations, personality, value orientations system, personal value orientation, socializing, interiorization, individualization, differentiation, integration.

\author{
Э.Т. ААимова', О.Х. Аймаганбетова', А. Серикхан"1, С.К. Жантикеев², А. Касым³ \\ 'Ә^-Фараби атындағы Қазақ ұлттық университеті, Қазақстан, Алматы қ., e-mail: elnura.adilova@mail.ru, \\ e-mail: alnara25@mail.ru, e-mail: ajoxot@gmail.com \\ ${ }^{2}$ Астана-Туран университеті, Қазақстан, Нұр-Сұлтан қ., е-mail: zhantikeyev_serik@mail.ru \\ ЗГГэлф университеті кросс-мәдени зерттеу орталығының қызметкері, Канада, e-mail:I.kassym@gmail.com
}

\section{Тұлға құрылымындағы құндылық бағдарлар жүйесінің орны мен рөлі}

Бұл мақала тұлға құрылымдағы құндылық бағдарлары жүйесінің орны мен рөлін зерттеуге арналған. Бұл мәселенің өзектілігі қазіргі саяси, экономикалық және әлеуметтік қайта құрулар жағдайында құндылық бағдарлары ерекше мәнге ие болатындығына байланысты, өйткені олар тұтастай тұлғаның қызмет етуі мен дамуын анықтайды.

Мақалада құндылық бағдарларының негізгі детерминанттары, сондай-ақ олардың тұлға құрылымындағы орнымен рөлінайқындаупроблемасы болыптабылатынәртүрлітұжырымдамалар мен көзқарастар берілген. Бұл, ең алдымен, ресей психологтарының тұжырымдамалары А.Н. Аеонтьев, Б.Г. Ананьева, А.В. Петровский, Н.Р.Са^ихова, шетелдік - Ж. Пиаже, А. Аэнгле, Н. Хоу мен У. Штраус және басқалар.

Мұнда бастысы қазақстандық зерттеуші А.Т. Ихсанованың құзіреттілікті дамыту моделін В.В. Козловтың интегративті көзқарас аясында қарастырылғаны. Мақалада автор ұсынған құндылық бағдарларының дамуының үш деңгейі қарастырылған, бұл олардың жеке тұлға құрылымындағы орны мен рөлін анықтауға мүмкіндік берді.

Беріген шолуда келесі тұжырымдарды жасауға мүмкіндік берді - құндылық бағдарлары адам өмірінің барлық салаларында көрінетін және оның мінез-құлқын реттейтін тұлға құрылымының маңызды құрамдас бөлігі. Осылайша, құндылық бағдарлары тұлға құрылымында маңызды орын алады. Бұл әр адамның өмірі үшін маңыздылығын жоғалтпайтын күрделі және көп қырлы әлеуметтік-психологиялық құбылыс.

Түйін сөздер: құндылық бағдары, тұлға, құндылық жүйелері, тұлғаның құндылық бағдары, әлеуметтену, интериоризация, дара^ау, дифференциация, интеграция. 
The Position and Role of the Value Orientations System in the Structure of Personality

\author{
Э.Т. ААимова1, О.Х. Аймаганбетова', А. Серикхан"1, С.К. Жантикеев², А. Касым³ \\ ${ }^{1}$ Казахский национальный университет им. аль-Фараби, Казахстан, г. А^маты, e-mail: elnura.adilova@mail.ru \\ e-mail: alnara25@mail.ru, e-mail: ajoxot@gmail.com \\ ${ }^{2}$ Университет Астана-Туран, Казахстан, г. Нур-Султан, e-mail: zhantikeyev_serik@mail.ru \\ зуниверситета Гуэлф, Канада, e-mail: I.kassym@gmail.com
}

Место и роль системы ценностных ориентаций в структуре кичности

\begin{abstract}
Аанная статья посвящена изучению места и роли системы ценностных ориентаций в структуре личности. Актуальность этой проблемы обусловлена тем, что в современных условиях политических, экономических и социальных трансформаций ценностные ориентации приобретают особую значимость, поскольку детерминируют функционирование и развитие мичности в целом.

В статье представлены различные концепции и точки зрения, в центре внимания которых находится проблема определения основных детерминант ценностных ориентаций, а также определения их места и роли в структуре кичности. Это, прежде всего, концепции российских психологов - А.Н. Аеонтьева, Б.Г. Ананьева, А.В. Петровского, Н.Р. Са^иховой, зарубежных -

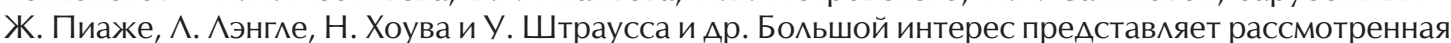
зАесь модель развития компетенций, сформулированная казахстанским исследователем А.Т. Ихсановой в рамках интегративного подхода российского психолога В.В. КозАова. В статье подробно рассмотрены предложенные автором три уровня развития ценностных ориентаций, что Аало нам возможность опреАелить их место и роль в структуре кичности.

Проведенный обзор позволил нам сделать вывод, что ценностные ориентации - это значимый компонент структуры кичности, проявляющийся во всех сферах жизни человека и регулирующий его поведение.

Кмючевые слова: ценностные ориентации, мичность, система ценностей, ценностные ориентации мичности, социализация, интериоризация, индивидуализация, Аифференциация, интеграция.
\end{abstract}

\section{Introduction}

Personal value orientations, like any other multi-valued interdisciplinary scientific concept, are interpreted differently in the works of different authors. In several studies, the concept of the "personal value orientations" essentially coincides with the terms that characterize the moral-need or semantic sphere.

Student age is one of the most important periods in life because, in addition to receiving professional education during that time, the transition to adulthood is also happening. It is when one starts to actively build their life path, testing various life strategies, becomes the subject of their life, finding their unique and individual lifestyle. However, the movement in this direction is dramatic since it is associated with the dilemma of value choice and the need to understand the individual meaning of life through the comparison of objective and subjective, personal and social. Young people, as writes W.T. Lisovsky, constantly get to decide what is more valuable for them: enrichment by any means or purchases of high requirements, providing ability to adapt to new conditions; denial of past moral norms or flexibility, adaptability to the new reality; boundless freedom in interpersonal and intersex relations or family, as a bulwark of successful existence (Lisovsky, 2002).
Young people's ability to project the future, evaluate the "different" things and keep the past in their memory depends on the awareness of their attitude towards the culture samples and ultimate possibilities that are kept in the values. There is a necessity of stable directions of values and meanings to make the right decision for that young people's problem.

\section{Main part}

The personality formation is completing during the process of assignment to the cultural and historical experience and values of the society one lives and is included in. Values as the social ideals are a part of the social communities' worldview that is made up of social consciousness and general images of perfection in different life domains that are consistent in it.

The system of value orientations determines the life perspective, the "vector" of the personal development, being its most important source and mechanism, and also is a psychological body that connects the personality and the social environment into a whole, performing the functions of regulating behavior and determining its purpose simultaneously. Values start gaining qualities of the actual motives and existence meanings' sources, leading to growth and personal progress in the process of self-sustained development. Thus, value orientations, being a 
psychological organ, a mechanism of personal growth and self-development, are themselves constantly evolving and represent a dynamic system. The system of value orientations of the personality, which performs both the functions of regulating behavior and determining its purpose, linking the personality and the social environment into a single whole, is such a psychological formation (Leontiev, 1999).

During the transition from childhood to adulthood, the consequence of the value measurement in one's life is the formation of a life plan system that defines the person's leading values in the form of life goals in various degrees of clarity and detail (Salikhova, 2009).

Jean Piaget associated the individual's value orientations' development with the levels of intellectual development. The internalization of moral judgments, he believed, occurs in children as a result of the interaction of developing thought structures with gradually expanding social experience.

A.N. Leontiev distinguishes internalization as a key mechanism for the personality's values and meanings formation, understanding it as the process of formation of the internal structures in the human psyche through the assimilation of external social activities'structure, or transformation of the objective structure to the internal plane of consciousness' structure (Leontiev, 2003). B.G. Ananyev considers interiorization as the development of social experience and culture, certain positions, roles, and functions. "All spheres of motivation and values are determined by this social personality formation" (Ananyev, 2001).

N.R. Salikhova believes that the value system sets the content of the lifeworld, and individual dynamics of the lifeworld may be described through the change of semantic and value contents as a change in the hierarchy of values, the emergence of new personal meanings and values, the loss of the former ones. The value-semantic sphere of personality performs the functions of life regulation, ensuring coordination of activities in various spheres of life and their compliance with the system of vital relations of the subject with the world (Salikhova, 2008).

In the value-semantic content of living space, depending on the semantic types of values, different value-semantic zones are distinguished, the configuration of which sets its value-semantic relief. The content of the value-semantic zone is determined by the content of the value, and the dynamic component is determined by its semantic type.
Laws that structure the personal living space in the aspect of the reflection of mismatches between the desirable and the possible with personal values, and the possibility of such mechanisms' occurrence is set to the special nature of values as affectiveintellectual formations, in which both affective and intellectual components act as a kind of hypergeneralizations, as it is noted by many authors.

On one hand, values exist in a specific form of generalized ideas that crystallize the cultural and historical experience of mankind. On the other hand, being appropriated by a man in the course of his ontogenetic development, the idea structures and regulates the main sources of his impulses, which connects it with the phenomena of affectiveneed nature, the generalization, and means of the signification of which it becomes. Due to the high level of generality of values, it is fundamentally impossible to give an objective assessment of their availability or realization in life. The regulatory role of values in life is associated with the need to detect and identify the content of values in reality when correlating ideas with sensory-specific characteristics of real situations and objects. Therefore, values are not always unambiguously and directly can be correlated with a particular life situation and "found" in it, which causes uncertainty in assessing their presence in life. The possibility of psychotherapeutic influence on a person is based on this values peculiarity, expanding, as L. Längle accurately expressed it, his experience of "touching the value" (Längle, 2005).

Value-semantic relief of living space reveals age specificity. The predominance of barrier zones in youth is recorded, which reflects the specificity of the internal position of a person at the beginning of adult life, associated with the expansion, conquest and development of social space. In early adulthood, there is an increase in realizability, and in the periods of middle adulthood, a multidirectional dynamics is recorded, depending on socio-cultural and professional-activity determinants.

With the changes in the internal position of a person in the system of life relations, it is possible to also link the fact of changing the relief of the living space within one age period, depending on the personality development phase within a stable social situation of development. Thus, after entering into a new development social situation, barrier semantic types of values prevail, and within the framework of the mastered - realized ones. Even though important people may continue being within the mastered social community, preparing to exit from it, and focus in one's inner experience, future-proof, 
the transition to a new social community, to which the person is still "not born" and the development degree, which is still minimal, is also evident in the barrier dominance and lowering the implemented component in the processes of meaning formation. This means that the barrier-realizability construct grasps those aspects of the inner position of the personality that make up its subjectively experienced side, reflecting the degree of development of its living space.

The transfer of this explanation principle on the barrier resistance performance as the instrumental values' feasibility allows interpreting them as a manifestation of development or dis-assimilation of the ME space. The predominance of the instrumental values barrier, when a person low estimates those qualities that are available to him, and high those that he considers inaccessible to themselves, means the lack of development of their manifestations and properties, while the shift to the pole of the realizability of instrumental values-their development. Empirically it has been proved for the study of life choices in youth, which showed that the choices in the direction of significant changes in life situations and the expansion of living space are associated with a predominance of the feasibility of instrumental values, and the choice in the direction of "leave it as it is" with the prevalence of their barrier role of instrumental values when a person is a low value the qualities that are available to him, and highly those who believe is inaccessible to itself, means the lack of development of his manifestations and properties, while the shift to the pole of the realizability of instrumental values-their development. Empirically it has been proved for the study of life choices in my youth in which it was shown that the choice in the direction significant changes in life situations and the expansion of living space associated with a predominance of the feasibility of instrumental values, and the choice in the direction of "leave as is" is due to their predominance of a barrier resistance.

In case of the prevalence of values' realizability, the person focuses on the near plans of vital space, is concentrated on local and exact reflection of that is within realized vital relations and activities, operational-semantic fields of the carried-out actions. What is available and mastering is included in the living space, whereas what is not available is not present in it at all or is on its very periphery. Here the inner is realized externally and thereby dissolves itself in the acquired objectivity. It provides immersion of the person in available vital space, cutting off all extraneous, causes the subjective feeling of it as spacious and mastered. The person is psychologically localized in the center of space, lives "here and now". But at the same time, it seems to be outlined by an invisible border, a person does not seek to expand it, the main "figure" is the nearest zones. Therefore, in describing this living space from an outside position, it can be described as centripetal and closed.

In the case of the predominance of barrier values, the image-background relations structuring in the living space is diametrically opposite. What is available is not noticed and appreciated. At the same time, a person is absorbed in what is beyond the available zone, it seems to him that everything basic in life and the world is not where he is, but somewhere in the "beautiful world". Here, the orientation to the distant plans of living space prevails, and the near ones are the background. The image of the world thus becomes much more voluminous, but its segments are perceived less accurately, approximately. The search for new opportunities (just as their own) requires correlation with internal criteria, so as a" figure" are their feelings, desires, aspirations, experiences. It is possible to speak about the subjective feeling of vital space as close, closed, empty, subjective localization of the person on its periphery, life "there and then" with feeling that "still only it is necessary" or "everything already was". When describing this living space from the outside, we can speak of it as centrifugal, directed to the expansion, outwards.

Generalization of theoretical and empirical results allowed N.R. Salikhova to assert that the parameter of the personal values' realizability reflects the work of a functional mechanism included in the implementation of feedback within the regulatory circuit at the level of life in general and mediating the work of mechanisms for identifying and deciding on the acceptance/rejection of the detected deviation from life goals. Carrying out verification of arising deviations on conformity to deep nuclear personal structures, this mechanism creates an existential installation on life space stabilization or on its change, which modulate perception of a vital situation by the subject, and prevalence of a barrier pole or a values' realizability pole represents opposite modes of work of this mechanism (Salikhova, 2010).

The stabilization setting corresponding to the mode of realizability operates in case of correspondence of the actual state to the deep personal value-semantic structures. That is, the person feels the correspondence of his activity and its results. In the opposite case, there is a change setting corresponding to the barrier mode, in which both the initial goal 
and the deviations that appear are evaluated by the subject as not corresponding to the zone of the nearest development. This is due to the exhaustion of the personal development potential in a particular semantic reality when there is no increment, novelty, neither the correction of performance nor the result deviated from the goal do not carry new opportunities for self-realization and self-development. A person experiences a life situation as not corresponding to his deep value-semantic core. As a result, the semantic search begins, the creation and "fitting" of various value-semantic contents as new opportunities for further self-realization, which is expressed in the tendency of mismatch of the importance and accessibility parameters.

The most important characteristic of the personal value orientations system is multilevel and hierarchical. For J. Gudecek, value orientation is horizontal, vertical structure: horizontal structure includes the order of values in the hierarchy of preferred and rejected values, a vertical structure is understood as the inclusion of individual values in the value system of the society as a whole. The rank of a value in the system of value orientations of the individual from different researchers are determined by various criteria: the height and strength of the value, depending on the degree of its realization, the degree of personal or social significance (Gudecek, 1989).

In the concept of S.S. Bubnova, along with the principle of hierarchy, the principle of multidimensionality and nonlinearity of the system of value orientations is highlighted, since the personal significance of values, which is a criterion for the hierarchy of the value system, includes various content aspects associated with the influence of different types and forms of social relations (Bubnova, 1994).

Investigating the problem of Genesis of value orientations, D.A. Leontiev proposed the concept of three forms of existence of values, passing one into another:

1) the social ideals developed by public consciousness and the generalized ideas present in it about perfection in various spheres of public life,

2) the objective embodiment of these ideals in the acts or works of specific people,

3) motivational structures of the person ("models of due"), inducing the person to the objective embodiment in their activities of social value ideals (Leontiev, 1998).

As D.A. Leontiev notes, these three forms of existence pass one into another: social ideals are assimilated by the person and as "models of due" begin to induce her to activity, in the process of which their objective embodiment occurs; objectively embodied values, in turn, become the basis for the formulation of social ideals. That is, the process of development of each person is characterized by the assimilation of the values of social communities and their transformation into personal values.

The formation and development of the system of value orientations of a person occurs simultaneously in several processes: according to V.A. Petrovsky, in the personalization process which involves adaptation (as the assignment of the individual's social norms and values); individualization (as a statement of the values of the "I") and integration (like the removal of contradictions between the values of individuals and groups by their transformation) (Petrovsky, 2000).

D.A. Leontiev describes the process of interiorization as a movement from the values of social groups to personal values. In this context, socialization is understood by him as the assimilation of the values of social communities, and their transformation into personal values (movement from the structure of individual motivation, based solely on needs, to a structure in which values play a dominant role (Leontiev, 1998).

L.V. Baeva points out that "the general mechanism of value formation can be represented as follows: the relationship of the subject and the object-subjective experience-comprehension of the meaning of the object, or giving it such-identification of the significance of the object-the statement of value as a synthesis of these transformations" (Baeva, 2003).

In the study of A.S. Sharov carried out under the leadership of V.G. Leontiev, the position is put forward that in the system-structural organization of the value-semantic sphere and regulation, two tendencies - differentiation and integration-manifest themselves. The holistic psychological organization of these processes, ensuring the performance of certain regulatory functions, is the psychological mechanism for changing the value-semantic sphere (Sharov, 2000).

M.S. Yanitsky identifies three main processes: adaptation, socialization, and individualization, which consistently occur in this order, are repeated at the appropriate new round of personal development and reflect at their level the balance of the influence of the individual and the environment on the formation of values (Yanitsky, 2012).

In adolescence, according to M.S. Yanitsky, one develops one's worldview, which creates the possibility of forming an internal, Autonomous 
system of values, so adolescence is crucial in terms of the formation of the value system of the individual. According To M. S. Yanitsky, the basis of the acquisition of the value system of actually acting characters is the awareness of the personal meaning of one's life. However, the dynamic system of value orientations does not stop there in its development during adulthood (Yanitsky, 2000).

P.Yu. Tazov identified 2 characteristic dominants of value systems, which set the vector of formation of the value system:

1. Adaptation - all social goals and objectives are implemented for successful adaptation in society. There is no deep internalization of values and norms.

2. Integration - social behavior is based on identification with certain social communities whose values and norms are recognized as leading.

The specificity of the choice of social models in a young person depends both on his value system and on the nature of the prospects for the development of society (Tazov, 2015).

B.I. Dodonov emphasizes the role of emotional reinforcement in the adoption of social norms, pointing out that «the orientation of a person to certain values can arise only because of their preliminary recognition (positive assessment rational or emotional)" (Dodonov, 1978).

G.M. Andreeva singles out family, school, labor collective, acting as "translators of social experience", in which the personality is attached to systems of norms and values as environmental factors of formation of the individual system of values (Andreeva, 2010).

W. Bronfenbrenner presents the sequence of stages of development of the system of value orientations of personality in the «model of ecological systems». According to it, the human life environment is a concentrically expanding system, where the previous system is included in another, wider system: Microsystem (eg, mother), mesosystem (family, school, peers, and neighbors), exosystem (extended family, place of work of parents, media), macrosystem (society as a whole, its laws, traditions, and values proper). Higherlevel systems affect the underlying ones, so the macro system has an impact on all the other levels (Bronfenbrenner, 1976).

Researchers long ago (Yu. A. Sherkovin, A. V. Sharikov and E. A. Baranova, Matveeva N. A., etc.). This problem has become particularly acute in the last decade due to the expansion of the Internet. M.S. Yanitsky believes that modern media do not so much form as only consolidate value preferences since the unlimited choice of the channel of receiving, form and content of information are conditioned by already existing values (Yanitsky, 2012).

D.O. Yerokhin considers mass communication as a factor in the formation of human values. In favor of this conclusion, the data on the role of mass communications as one of the most significant sources of psychological influence exerted on the modern man - both at the individual level and on the scale of large social groups. The author created the concept of the three-level communicative impact of media messages on the value system of the individual. These three levels of transformation correspond to the main components of value orientations: motivational, cognitive and evaluative (installation-behavioral). Accordingly, these tremors influence the value system that occurs when an individual perceives images, values and role models contained in messages broadcast through mass media (Yerokhin, 2011).

The category of subjective psychological factors of the values formation is, first of all, the features of the motivational-need sphere and personal characteristics. The formation of personal values occurs in conjunction with various personal properties. People with different personality characteristics adapt differently, change their priorities and personal values. Summarizing the results of various studies, N.A. Zhuravleva identifies some groups of personal characteristics that affect the formation of personal values: conformism/ nonconformism, suggestibility, self-control; activity, energy; strong-willed qualities, determination; the level of personal claims; motivation to achieve: striving for success and avoiding failure; focus on the case, on interaction with other people, on yourself; stress resistance; flexibility/rigidity; intelligence, thinking, learning. (Zhuravleva, 2006).

The parental family as a source of formation of values, installations, and norms of behavior is investigated most widely. M.S. Yanitsky, summarizing the data of various authors, gives a list of the main factors mediating the influence of the family on the formation of the value system of the individual. This is the structure of the family (full or incomplete composition, the presence of brothers and sisters, elders, parents); types of education and styles of parental behavior; conflict or non-conflict nature of the relationship between parents; social status, level of education and income of parents; socio-cultural, religious and ethnic roots of the family (Yanitsky, 2012).

T.I. Shnurenko in her dissertation research traced the dynamics of value orientations of students 
in the conditions of intergenerational continuity. The study revealed the features of the mechanism of succession:

- the younger generation's value system formation cannot be carried out except based on the value system of older generations;

- the mechanism of stable elements' transmission of experience from generation to generation are the basic values that the successor learns and learns, some of them reject and based on creatively meaningful, the younger generation creates new values;

- the succession mechanism involves confrontation and conflict of generations at the value level;

- the succession process between the generations can be both conscious and unconscious. Its structure is characterized by continuity, consistency, consistency, relative constancy, deviation from unambiguous relaying, creativity and innovation (Shnurenko, 2009).

In the course of the study, the author revealed that the value field of the older, middle and younger generation groups simultaneously contains the basic values of traditional Russian culture, ideologized values of the Soviet era and liberal trends of the last decades. Most representatives of the studied generational groups are integrated into modern society and retain only elements of adherence to the traditional type of culture.

The values that unite different generations are revealed. Among them: altruism, kindness, help, and mercy to others, vitality, authority, disregard for wealth at the level of tradition and the importance of high material well-being at the level of behavior.

What differentiates generations are the values of achievement, stimulation, conformity, luxury living, fame, and popularity.

The cultural specificity of the continuity mechanism is double standardized, which is manifested in the fact that the younger generation, assimilating the values of older generations, along with the content of values, assimilates the discrepancy between the declared values and the real structure of values. Features of the values intergenerational continuity mechanism in modern Russia is that, despite the deep transformation that is taking place in Russia, value orientations of Russian tend to preserve their basic value component which is the transmission mechanism stable elements of the value system from generation to generation.

At the level of normative ideals, value continuity is preserved, a continuous value process is revealed, going from the older generation to the middle and younger generations. There is a continuity of values from the older generation to the middle generation group, and a smaller value relationship between the older generation and the younger generation.

According to N. Howe and W. Strauss, the fundamental values of people change after a certain amount of time and directly depend on the same events that these people have experienced (political, economic, social, technological), as well as on the principles of their education. Values formed before the age of 12-14 are subconscious and sometimes implicit for their owners, but throughout life, each generation inevitably lives and acts under their influence. The difference of these values can generate difficulties of communication between representatives of different generations in society (Khomyakova, 2011).

As part of their concept, the authors identify six generations living today: "the G. I. Generation", "the Silent Generation"," the Boom Generation"," Generation X"," the Millennial Generation", "the Homeland Generation". The theory based on this classification is valid relatively for the entire population of people.

The Russian scientist psycholinguist Evgenia Shamis in the project "Ru Generations" adapted the theory of generations for the CIS countries. According to her version, the following descriptions turned out:

1. The GI generation (the generation of Winners). Years of birth: 1900-1923. Events that influenced the formation of values: the revolutions of 1905 and 1917, mass movements from villages to cities, collectivization, electrification. Values: willingness to change and belief in a bright future, hard work, responsibility, commitment to ideology, family traditions, categorical judgments.

2. The silent generation. Years of birth: 19231943. They are patient, executive, accustomed to surviving generation got its name for the strict observance of norms and laws. Their values, which were formed during the Second world war, are loyalty, observance of rules, honor, patience.

3. The babyboomers generation so named because of the postwar birth boom (1943-1963). Events that influenced the formation of values: the victory in world war II, Yuri Gagarin's flight into space, the introduction of uniform standards of education in schools and guaranteed medical care. Their values were: optimism, the achievement of high results, interest in personal growth and, at the same time, collectivism and team spirit. 
4. Generation X (Unknown generation). Years of birth: 1963-1983. Events that shaped values: the continuation of the cold war, perestroika. Values: readiness for change, choice, global awareness, independence, gender equality, the informality of views, search for emotions, pragmatism, materialism, high level of material ambitions. The key concepts are money and things.

5. Generation Y (Millennium generation). Years of birth-1983-2003. Their values continue to be formed until now. Events that influenced the formation of values: the collapse of the USSR, terrorist attacks, the development of digital and biotechnology. Values: freedom, fun (fun), the result as such. The value system of this group already includes such concepts as civic duty, morality, responsibility, but psychologists note their naivety and ability to obey. Immediate rewards come to the fore for generation Y. The key concept is a success.

Based on empirical data and theoretical analysis of the problem of value orientations, Kazakh psychologist D.T. Ihsanova proposed a model of development of value orientations. The model of development of value orientations is built based on the integrative approach in psychology and taking into account the revealed features of the students' values sphere development (Ihsanova, 2010). The model developed by the author assumes three levels of development of value orientations in the process of integration.

The first level is the individual's awareness of value orientations. Awareness of value orientations is the first impetus to the mastery of new behaviors. However, awareness of value orientations alone is not a sufficient condition for a real change in behavior. Such awareness can only serve as the first stage. True awareness becomes apparent when new elements of behavior are assimilated by the individual and, accordingly, become arbitrary and conscious.

The second level of the modes implementation is the adoption of personal value orientations. After the process of awareness of value orientations by the person, the next stage is the adoption of their value orientations. In the course of this transformation, there is an acceptance of responsibility. Positive accentuation of the acquired experience promotes the formation of installation on acceptance of failure. To form such an attitude, it is necessary to pay attention to the development of a large number of roles and goals of the individual. The adoption of value orientations implies the inclusion of new response strategies and the integration of universal values into personal ones. Acceptance of value orientations is key to the possibility of change. At this stage, a large number of difficulties often arise. The adoption of value orientations by a person implies the construction of a hierarchy of values.

The third level is the realization of value orientations by a person. At this stage, the main emphasis is on the consolidation of new behavioral patterns, the development of skills of self-analysis of value orientations and ways to realize their potential. In the process of realization of value orientations, there is a further formation and development of personality depending on the nature of the interaction of the individual with the environment. Thus, realizing value orientations, in constantly changing conditions, the individual not only learns new experiences but reproducing, changing social relations.

Consequently, value orientations are conscious, learned and accepted by the individual social norms and values that act as goals of life and means of achieving these goals (Ihsanova, 2013).

Thus, in the personal value orientations system development, researchers identify several features. Value orientations affective-intellectual generalized education, organized in a dynamic system that determines the life perspective, the "vector" of personality development, being its most important source and mechanism, a psychological body that binds into a whole personality and social environment, performing simultaneously the functions of regulating behavior and ensuring coordination of activities in various spheres of life.

The value-semantic relief of living space has age specificity. The predominance of barrier zones in youth is noted, which reflects the specificity of the internal position of a person at the beginning of adult life, associated with the expansion, conquest, and development of social space. In early adulthood, there is an increase in realizability, and in the periods of middle adulthood, a multidirectional dynamics is recorded, depending on socio-cultural and professional-activity determinants.

Indicators of barrier resistance-the feasibility of instrumental values indicates the degree of development or disassimilation in the ME space. the Prevalence of a barrier resistance instrumental values, when a person is a low value the qualities that are available to him, and highly those who believe is inaccessible to itself, means disassimilation in the ME space, while the shift to the pole of the feasibility of 
instrumental values - their development. In case of the prevalence of realizability of values, the person focuses on near plans of living space, "here and now".

The formation and development of the system of value orientations of the individual occur simultaneously in several processes:

- socialization;

- internalization (adaptation);

- individualization;

- differentiation and integration.

According to S.A. Belicheva, suggestion, imitation, and identification predominate as mechanisms of internalization of external group norms and values in childhood. As the child grows and develops, other mechanisms of socialization begin to prevail - reference groups, prestige, authority.

However, the formation of value orientations of the individual in the process of socialization, despite the awareness of the assimilation of values of the social environment, does not imply the independent development of their internal values. In this regard, several authors oppose the process of the socialization process of individualization, which may be defined as a separate, the most "top" in comparison with adaptation and socialization process of development of the system of value orientations of the individual. According to M.S. Yanitsky, individualization is understood as a process of forming an Autonomous system of values. In foreign humanistic psychology, this process is referred to as internal growth or development, the implementation of personal meaning, self-actualization.

\section{Conclusion}

The development of value orientations is closely related to personality orientation development. Everyone may have their system of values, and in this system of values, they are built in a certain hierarchical relationship. Currently, life values are mostly formed spontaneously and under the influence of various factors. The value orientations acquired in the process of development depend on what activity the person is involved in. The system of personal value orientations, being a reflection of the social environment values, may itself have an impact on the group norms and values. Individual value orientations of group members interact and influence on collective relationships through interpersonal relationships.

From the above, the following conclusions may be drawn:

- The system of personal value orientations is a complex, multi-level and heterogeneous structure.

- The development of the personal value orientations system is carried out by several simultaneously occurring and interrelated processes, besides, the influence is exerted by the action of various internal and external factors.

- The personal value orientations' formation in the process of its socialization is carried out by assimilation of significant ones through identification, and the assignment of social values by interiorization.

- During growing up, the personal value orientations' formation is more and more influenced by belonging to certain large socio-cultural groups.

\section{References}

Ananyev B.G. (2001) O problemah sovremennogo chelovekoznaniya [On the problems of modern human of knowledge]. SPB.: Peter, $272 \mathrm{p}$.

Andreeva G.M. (2010) Sotsialnaya psihologiya [Social Psychology]. M.: Aspect Press, 368 p.

Baeva L.V. (2003) Tsennostnye osnovaniya individualnogo bytiya: Opyt ekzistentsialnoi aksiologi [Value Foundations of Individual Being: The Experience of Existential Axiology]. M.: Prometei: MPGU, 240 p.

Bronfenbrenner W. (1976) Dva mira detstva. Deti v SShA i SSSR [Two worlds of childhood. Children in the USA and the USSR]. Moscow, 165 p.

Bubnova S.S. (1994) Metodika diagnostiki individualnoi struktury tsennostnyh orientats11 lichnosti. Metody psihologicheskoi diagnostiki [Diagnostic technique of the individual structure of value orientations of the personality. Methods of psychological diagnosis / ed. A. N. Voronin. M.: Institute of Psychology, Russian Academy of Sciences. Release 2, pp. 144-157.

Gudecek J. (1989) Tsennostnaia orientatsiya lichnosti. Psihologiya lichnosti v sotsialisticheskom obestve: Aktivnost i razvitie lichnosti [Value orientation of a person. Psychology of a personality in a socialist society: Activity and development of a personality]. M., pp. 202-109.

Dodonov B.I. (1978) Emotsiya kak tsennost [Emotion as a value]. M., 272 p.

Erokhin D.O. (2011) Informatsionnaiya sreda kak faktor formirovaniya tsennostei molodeji [Information environment as a factor in the formation of youth values]: abstract... cand. psychol. of sciences. M., 29 p. 
Zhuravleva N. A. (2006) Dinamika tsennostnyh orientatsi lichnosti v ross11skom obchestve [Dynamics of personality value orientations in Russian society]. M.: Institute of Psychology RAS, 335 p.

Ihsanova D.T. (2010) Razvitie tsennostnyh orientatsi studentov v protsesse adaptatsi k obucheniy v vysshem uchebnom zavedeni [The development of students' value orientations in the process of adaptation to education in a higher educational institution]: abstract... cand. psychol. of sciences. Almaty, 27 p.

Ihsanova D.T., Aimaganbetov A.B. (2013) Sotsialno-psihologicheskie osobennosti razvitiya tsennostnyh orientatsi v ynosheskom vozraste [Socio-psychological characteristics of the development of value orientations in adolescence]. Bulletin of KazNU. Series of psychology and sociology, no 2, pp.23-33.

Leontiev A.N. (2003) Stanovlenie psihologi deiatelnosti [The formation of the psychology of activity]. M.: Sense, 440 p.

Leontiev D.A. (1999) Psihologiya smysla: priroda, struktura i dinamika smyslovii realnosti [Psychology of meaning: nature, structure and dynamics of semantic reality]. M.: Sense, $486 \mathrm{p}$.

Leontiev D.A. (1998) Tsennostnye predstavleniya v individualnom i gruppovom soznani: vidy, determinanty i izmeneniya vo vremeni [Value representations in individual and group consciousness: types, determinants and changes in time]. Psychological Review, no 1, pp. 13-25.

Lisovsky V.T. (2002) Sotsialnye izmeneniya v molodejnoi srede [Social changes in the youth environment]. Credo New, no1, pp. 35-45.

Längle A. (2005) Viktor Frankl - poverennyi chelovechnosti [Victor Frankl - Attorney for Humanity]. Psychology Issues, no 3 , pp. 107-111.

Petrovsky A.V. (2000) Teoriya lichnosti s pozitsi kategorialnogo analiza psihologi. Psihologiya lichnosti v trudah otechestvennyh psihologov [The theory of personality from the perspective of a categorical analysis of psychology. Psychology of personality in the works of domestic psychologists]. SPB.: Peter, pp. 75-83.

Salikhova N.R. (2010) Kontekstualno-yrovnevaiya model jiznennogo prostranstva lichnosti [Context-level model of the living space of a person]. Uchenye zapiski Kazan University. Series "Humanities". Book 5, vol.152, pp.183-199.

Salikhova N.R. (2008) Mehanizm barernosti-realizuemosti lichnostnyh tsennostei v strukturirovani jiznennogo mira cheloveka [The mechanism of barrier-realizability of personal values in the structuring of the human life world]. Bulletin of Novosibirsk State University. Series Psychology, no 1, pp. 36-40.

Salikhova N.R. (2009) Realizuemost lichnostnyh tsennostei v stanovleni jiznennogo mira cheloveka [Realizability of personal values in the formation of the human life world]. Siberian Psychological Journal, no 32, pp. 40-45.

Tazov P.Yu. (2015) Dinamika tsennostei studentov: ot tsennostei integratsi k tsennostiam adaptatsi [Dynamics of student values: from integration values to adaptation values]. Bulletin MIRBIS, no 1, pp. 37-42.

Khomyakova E.I. (2001) «Pokolenie Y» v kontekste sotsiialnogo vzaimodeistviya v sovremennom obestve ["Generation Y” in the context of social interaction in modern society]. Bulletin of the Tomsk Polytechnic University, no 6, pp. 153-156.

Sharov A.S. (2000) Sistema tsennostnyh orientatsi kak psihologicheski mehanizm reguliatsi jiznedeiatelnosti cheloveka [The system of value orientations as a psychological mechanism for regulating human life]: abstract... cand. psychol. sciences. Novosibirsk, $41 \mathrm{p}$.

Shnurenko T.I. (2009) Tsennostnye orientatsi studencheskoi molodeji kak rezultat mejpokolennoi preemstvennosti [Value orientations of student youth as a result of intergenerational continuity]: author... doc. psychol. sciences. Kursk, 25 p.

Yanitsky M.S. (2012) Tsennostnoe izmerenie massovogo soznaniya [Value measurement of mass consciousness]. Novosibirsk: Siberian Branch of the Russian Academy of Sciences, 237 p.

Yanitsky M.S. (2000) Tsennostnye orientatsi lichnosti kak dinamicheskaiya sistema [Value orientations of personality as a dynamic system]. Kemerovo: Kuzbassvuzizdat, 204 p.

\section{Литература}

Ананьев Б.Г. О проблемах современного человекознания. - СПб.: Питер, 2001. - 272 с.

Андреева Г.М. Социальная психология. - М.: Аспект-Пресс, 2010. - 368 с.

Баева Л.В. Ценностные основания индивидуального бытия: Опыт экзистенциальной аксиологии. - М.: Прометей: МПГУ, 2003. $-240 \mathrm{c}$.

Бронфенбреннер У. Два мира детства. Дети в США и СССР. - М., 1976. - 165 с.

Бубнова С.С. Методика диагностики индивидуальной структуры ценностных ориентаций личности. Методы психологической диагностики /под ред. А. Н. Воронина. - М.: Институт психологии РАН, 1994. - Вып. 2. - С.144- 157.

Гудечек Я. Ценностная ориентация личности // Психология личности в социалистическом обществе: Активность и развитие личности. - М., 1989. - С.202-109.

Додонов Б.И. Эмоция как ценность. - М., 1978. - 272 с.

Ерохин Д.О. Информационная среда как фактор формирования ценностей молодежи: автореф...канд. психол. наук. М., 2011. -29 c.

Журавлева Н. А. Динамика ценностных ориентаций личности в российском обществе. - М.: Институт психологии РАН, 2006. -335 c. 240

Ихсанова Д.Т. Развитие ценностных ориентаций студентов в процессе адаптации к обучению в высшем учебном заведении: автореф...канд. психол. наук. - Алматы, 2010. - 27 с.

Ихсанова Д.Т., Аймаганбетов А.Б. Социально-психологические особенности развития ценностных ориентаций в юношеском возрасте // Вестник КазНУ. Серия психологии и социологии. - 2013. - № 2. - С.23-33. 
Леонтьев А.Н. Становление психологии деятельности. - М.: Смысл, 2003. - 440 с.

Леонтьев Д.А. Психология смысла: природа, структура и динамика смысловой реальности. - М.: Смысл, 1999. - 486 с. Леонтьев Д.А. Ценностные представления в индивидуальном и групповом сознании: виды, детерминанты и изменения во времени // Психологическое обозрение. - 1998. - № 1. - С. 13-25.

Лисовский В.Т. Социальные изменения в молодёжной среде // Credo New. - 2002. - №1 - - С. 35-45.

Лэнге А. Виктор Франкл - поверенный человечности // Вопросы психологии. - 2005. - №3. - С.107 - 111 .

Петровский А.В. Теория личности с позиций категориального анализа психологии. Психология личности в трудах отечественных психологов. - СПб.: Питер, 2000. - С.75-83.

Салихова Н.Р. Контекстуально-уровневая модель жизненного пространства личности // Ученые записки Казанского университета. Серия «Гуманитарные науки». - 2010. - Книга 5, т. 152. - С. 183-199.

Салихова Н.Р. Механизм барьерности-реализуемости личностных ценностей в структурировании жизненного мира человека// Вестник НГУ. Серия: психология. - 2008. - №1. - С.36-40.

Салихова Н.Р. Реализуемость личностных ценностей в становлении жизненного мира человека // Сибирский психологический журнал. - 2009. - №32. - С.40-45.

Тазов П.Ю. Динамика ценностей студентов: от ценностей интеграции к ценностям адаптации // Вестник МИРБИС. 2015. - №1. - С.37-42.

Хомякова Е.И. «Поколение Ү» в контексте социального взаимодействия в современном обществе// Известия Томского политехнического университета. - 2011. - №6. - С.153-156.

Шаров А.С. Система ценностных ориентаций как психологический механизм регуляции жизнедеятельности человека: автореф...канд. психол. наук. - Новосибирск, 2000. - 41 с.

Шнуренко Т.И. Ценностные ориентации студенческой молодежи как результат межпоколенной преемственности: автореф. ... док. психол. наук. - Курск, 2009. - 25 с.

Яницкий М.С. Ценностное измерение массового сознания. - Новосибирск: СО РАН, 2012. - 237 с.

Яницкий М.С. Ценностные ориентации личности как динамическая система. - Кемерово: Кузбассвузиздат, 2000. - 204 c. 